\title{
Platelet-activating Factor
}

\section{A Potent Chemotactic and Chemokinetic Factor for Human Eosinophils}

\author{
A. J. Wardlaw, R. Moqbel, O. Cromwell, and A. B. Kay \\ Department of Allergy and Clinical Immunology, Cardiothoracic Institute, Brompton Hospital, London, SW3 6HP, United Kingdom
}

\begin{abstract}
Platelet-activating factor (PAF-acether), an inflammatory mediator with a wide range of biological activities including neutrophil aggregation and chemotaxis, was studied for its effect on human eosinophil locomotion (chemotaxis and chemokinesis). Human eosinophils (25-95\% purity) were obtained from donors with a variety of diseases associated with hypereosinophilia. PAF-acether elicited directional locomotion of eosinophils, in a time- and dose-dependent fashion, at concentrations from $10^{-5}$ to $10^{-8} \mathrm{M}$; lyso-PAF had minimal activity over the same dose range. Compared with PAF-acether, the eosinophil locomotory responsiveness of leukotriene $\mathrm{B}_{4}\left(\mathrm{LTB}_{4}\right)$, histamine, and the valyl- and alanyl-eosinophil chemotactic factor of anaphylaxis (ECF-A) tetrapeptides was negligible. Conversely, neutrophil responsiveness to PAF-acether (optimum $10^{-6} \mathrm{M}$ ) was comparable in effect to $\mathrm{LTB}_{4}$ (optimum dose $10^{-8} \mathrm{M}$ ). It was shown that PAF-acether elicited both chemotaxis and chemokinesis of eosinophils. Comparison of normal density and light density eosinophils revealed no qualitative difference in the response to PAF-acether and the other chemoattractants, although the light density cells seemed to demonstrate a greater degree of locomotion to PAF-acether and $\mathrm{LTB}_{4}$. Thus, PAF-acether appears to be a potent eosinophilotactic agent which may play a role in inflammatory reactions characterized by eosinophil infiltration.
\end{abstract}

\section{Introduction}

Platelet-activating factor (PAF) ${ }^{1}$ or here PAF-acether, identified as 1-O-alkyl-2-acetyl $s n$-glycero-3-phospho-choline (1), is a potent inflammatory mediator with a wide range of biological activities (2). It was originally identified in supernatants from sensitized rabbit basophils challenged with antigen (3) but has since been shown to be generated by several human cell types including macrophages, neutrophils, eosinophils, and endothelial cells after a variety of physiologic and nonphysiologic stimuli (4-7). Its biological activities in human tissue include platelet aggregation and secretion (8), bronchoconstruction (9), monocyte chemotaxis (10), and inflammatory changes in skin (11). Its effects on neutrophils have been studied in detail and include chemotaxis and

Address reprint requests to Dr. Kay.

Received for publication 18 June 1986.

1. Abbreviations used in this paper: ECF-A, eosinophil chemotactic factor of anaphylaxis; hpf, high power field; HPLC, high-performance liquid chromatography; $\mathrm{LTB}_{4}$ and $\mathrm{LTC}_{4}$, leukotrienes $\mathrm{B}_{4}$ and $\mathrm{C}_{4} ; \mathrm{PAF}$-acether, platelet-activating factor.

J. Clin. Invest.

(c) The American Society for Clinical Investigation, Inc.

0021-9738/86/12/1701/06 $\$ 1.00$

Volume 78, December 1986, 1701-1706 chemokinesis, aggregation, and degranulation $(12,13)$. In contrast, there have been few reports of its effects on eosinophils. A recent study has suggested that it may enhance leukotriene $\mathrm{C}_{4}$ ( $\mathrm{LTC}_{4}$ ) release from eosinophils (14), and in animal models, inhalation of PAF has caused an increase in the percentage of eosinophils recovered in bronchoalveolar lavage (15). There have not been any detailed reports of its effects on eosinophil chemotaxis, although one investigator suggested it had only a minimal effect (16). For these reasons we have investigated the effect of PAF-acether on eosinophil locomotion (chemotaxis and chemokinesis) and have compared the effects of PAF-acether with lyso-PAF (an immediate precursor and metabolite of PAFacether) in addition to a number of documented and chemically characterized eosinophil chemoattractants.

\section{Methods}

Reagents and buffers. Synthetic PAF-acether (C16) and lyso-PAF (C16) (Bachem U. K. Ltd., Saffron Waldon, Essex, U. K.) were dissolved in chloroform/methanol $(9: 1)$ and stored at $-80^{\circ} \mathrm{C}$ until required. Leukotriene $\mathrm{B}_{4}\left(\mathrm{LTB}_{4}\right)$, a generous gift from Dr. Rokach (Merck Frosst Laboratories, Quebec, Canada), was dissolved in methanol at $-80^{\circ} \mathrm{C}$. The purity of the synthetic PAF-acether and $\mathrm{LTB}_{4}$ was determined by highperformance liquid chromatography (HPLC). PAF-acether coeluted as a single peak with $\left[{ }^{3} \mathrm{H}\right] \mathrm{PAF}$-acether (Amersham International, Amersham, Bucks., United Kingdom) using the method described by Jackson et al. (17). Straight-phase HPLC was performed on a $5-\mu \mathrm{m}$ spherical silica liquid chromatography column $(25 \mathrm{~cm} \times 4.6 \mathrm{~mm})$ (Anachem Ltd., Luton, Beds., United Kingdom) and eluted at $2 \mathrm{ml} / \mathrm{min}$ with acetonitrile/ methanol/85\% phosphoric acid (130:5:1.5 [vol/vol/vol]) as an eluting solvent. Column eluents were monitored at $203 \mathrm{~nm}$ and synthetic PAFacether was assayed by platelet aggregation. Markers used were phosphatidylcholine, lysophosphatidylcholine, and sphingomyelin. Synthetic $\mathrm{LTB}_{4}$ coeluted as a single peak with $\left[{ }^{3} \mathrm{H}\right] \mathrm{LTB}_{4}$ (New England Nuclear, Southampton, United Kingdom) on HPLC performed as described previously (18). Other reagents used and their sources were as follows: histamine dihydrochloride, valine-glycine-serine-glutaminic acid (Val-GlySer-Glu), alanine-glycine-serine-glutaminic acid (Ala-Gly-Ser-Glu), bovine serum albumin grade $\mathrm{V}$, and chicken egg albumin grade VI (Sigma Chemicals Ltd., Poole, Dorset, United Kingdom); Ficoll-Paque (Pharmacia Fine Chemicals AB, Uppsala, Sweden); Dextran 110 Injection BP (Fisons Pharmaceuticals, Loughborough, United Kingdom); heparin sodium 1,000 U/ml (Paine \& Byrne Ltd., Greenford, United Kingdom).

Buffers were RPMI 1640 with $25 \mathrm{mM}$ Hepes and L-glutamine (Gibco Ltd., Paisley, Scotland)-supplemented with $\mathrm{Ca}^{2+}$ and $\mathrm{Mg}^{2+}$ to a concentration of $10^{-3} \mathrm{M}$ Hanks' balanced salt solution without $\mathrm{NaHCO}_{3}$ (Gibco Ltd.).

Chemotaxis chambers. Macrochemotactic chambers consisted of upper chambers, Kay tubes (Technical Moulding Services Ltd., Midlothian, Scotland), lower chambers, polyethylene specimen tubes PST101 (Camlab Ltd., Cambridge, United Kingdom), 8- $\mu \mathrm{m}$ nitrocellulose filter paper (Sartorius Instruments Ltd., Belmont, Surrey, United Kingdom), and 48-well microchemotaxis chambers (Neuro Probe, Inc., Cabin John, MD).

Preparation of eosinophils and neutrophils. Blood was obtained from volunteers with an eosinophilia resulting from a variety of causes and separated by sedimentation with Dextran for $45 \mathrm{~min}$ at room temperature 
using heparin $(20 \mathrm{U} / \mathrm{ml})$ as an anticoagulant. The leukocyte-rich plasma was layered on a cushion of Ficoll-Paque and centrifuged at $300 \mathrm{~g}$ for $20 \mathrm{~min}$. Erythrocytes in the granulocyte-rich pellet were lysed using ammonium chloride buffer and the granulocytes were washed twice in Hanks' (pH 7.4) at $150 \mathrm{~g}$ for $10 \mathrm{~min}$ at $+4^{\circ} \mathrm{C}$. The cells were resuspended in RPMI 1640, and the total number of cells and percentage of eosinophils were counted in a modified Neubauer chamber using Kimura's stain (19). Granulocytes were diluted to $2 \times 10^{6}$ cells $/ \mathrm{ml}$ ready for use in the chemotaxis assay.

Locomotioñ assay. Locomotion was assessed using a modified Boyden chamber, as previously described (20). In brief, $1 \mathrm{ml}$ of cell suspension in $\mathbf{0 . 4 \%}$ ovalbumin was placed in the upper chamber separated from 0.8 $\mathrm{ml}$ of chemoattractant in the lower chamber by an 8- $\mu \mathrm{m}$ nitrocellulose filter. Solutions of PAF-acether, lyso-PAF, and $\mathrm{LTB}_{4}$ were evaporated over nitrogen and redissolved in RPMI $+0.25 \%$ bovine serum albumin (BSA). Histamine and the eosinophil chemotactic factor of anaphylaxis (ECF-A) tetrapeptides were also dissolved in this buffer. The $\mathrm{pH}$ of the buffer was adjusted to 7.4 after addition of the chemoattractant where necessary. The chambers were placed in a box to minimize evaporation and incubated at $37^{\circ} \mathrm{C}$ for $3 \mathrm{~h}$ in a dry incubator, unless otherwise stated. Diluent controls were included in each assay. The filters were then washed in normal saline, and fixed in saturated mercuric chloride/ethanol (50: 50) for a minimum of $\mathbf{4 5} \mathrm{min}$, before being stained with hemotoxylin and chromotope $2 R$. In neutrophil chemotaxis experiments, neutrophils were prepared in the same way, using blood from normal volunteers with a $1 \frac{112-h}{2}$ incubation period. Filters were fixed in industrial methylated spirits for $45 \mathrm{~min}$ and stained with hematoxylin. The filters were then mounted and left overnight at $+4^{\circ} \mathrm{C}$ before counting. Each assay was performed in duplicate and the filters were randomly coded by an independent investigator and read in a blind fashion. The number of cells that had migrated through to the underside of the filters in the area of a graticule on the $\times \mathbf{4 0}$ objective were counted. Results were expressed as the number of cells per 10 high power fields (hpf). The intra-assay coefficient of variation was $13 \%$ and duplicates did not differ from the mean by $>12.5 \%$.

The eosinophils used in the method described above consist of a mixture of normal density and low density eosinophils (21). It was possible that these two cell populations may exhibit different responsiveness to a chemotactic stimulus. To investigate this we prepared homogeneous populations of eosinophils using a discontinuous metrizamide gradient (22) and assessed the response of the eosinophils to PAF-acether and the other chemoattractants using a microchemotaxis method (23). In brief, for the normal density eosinophils, blood was obtained from donors with an eosinophilia of $\sim 10 \%$ and normal density (specific gravity $>1.1287$ $\mathrm{g} \mathrm{ml}^{-1}$ ) eosinophils of $45-80 \%$ purity were obtained from the metrizamide gradient. The cells were lysed and washed as above and were placed in the upper part of the chamber at a concentration of $4 \times 10^{6}$ cells $/ \mathrm{ml}$ separated by a nitrocellulose filter from the lower half. The chamber was incubated for $1 \frac{1 / 2}{\mathrm{~h}}$ in a $\mathrm{CO}_{2}$ incubator and the filter was stained and counted as above, each assay being performed in triplicate. The intraassay coefficient of variation was $10 \%$. Light density eosinophils (specific gravity $1.1177 \mathrm{~g} \mathrm{ml}^{-1}$; purity $28-80 \%$ ) were obtained from patients with an eosinophilia of $>30 \%$ and prepared in the same way. In a further set of experiments using normal density eosinophils prepared as above, we investigated the influence of the contaminating neutrophils on PAFacether-induced eosinophil chemotaxis. Eosinophils of $>90 \%$ purity were mixed with neutrophils from the same metrizamide gradient to compare the degree of eosinophil locomotion to PAF-acether with the percentage of contaminating neutrophils.

Assays within each experiment were performed on different eosinophil donors and comparison of chemoattractants was performed as part of the same assay. A total of nine donors were used in the macro-Boyden chamber method and 10 donors for the experiments involving the microchemotaxis method. Neither the cause of the eosinophilia nor the medications the donors were taking, including corticosteroids in some cases, appeared to have any influence on the locomotive response of the eosinophils.

Statistics. Locomotion of eosinophils to PAF-acether and other che- moattractants was compared using the two-tailed paired Student's $t$ test. Comparison of the effect of chemokinesis and chemotaxis was performed using a three-way analysis of variance.

\section{Results}

PAF-acether had a marked effect on eosinophil locomotion over a wide dose range when compared with lyso-PAF which had a negligible effect. PAF-acether was active between $10^{-8}$ and $10^{-5}$ $M$, with optimum effect at $10^{-6} \mathrm{M}$. We have also confirmed that PAF-acether causes neutrophil locomotion with a similar doseresponse curve to eosinophils and that lyso-PAF has minimal effect (Fig. 1). Compared with $\mathrm{LTB}_{4}$, PAF-acether was considerably more effective for eosinophils. Both mediators caused similar degrees of neutrophil locomotion but $\mathrm{LTB}_{4}$ had an optimum effect at a 10 times lower concentration than PAF-acether (Fig. 2).

PAF-acether had considerably greater effect on eosinophil locomotion than either histamine or the two ECF-A peptides, Val-Gly-Ser-Glu and Ala-Gly-Ser-Glu (Fig. 3). The effect of these three established chemoattractants was inconsistent and negligible.

The Boyden chamber technique does not distinguish between random motility (chemokinesis) and directional movement (chemotaxis) (24). To separate the relative contributions of chemokinesis and chemotaxis to PAF-acether-induced eosinophil locomotion, we compared locomotion observed with equal concentrations of PAF-acether above and below the filter (when any migration observed will be due to chemokinesis) with locomotion observed with PAF-acether only in the lower well (where migration will be due to a combination of chemokinesis and chemotaxis) (Fig. 4). There was a significant difference $(P<0.01)$ between the two modes of locomotion, showing that PAF-acether has both chemokinetic and chemotactic effects in common with most chemotactic factors.

In order to establish that the counts were not influenced by cells becoming detached from the underside of the filter, we performed a time course of incubation. This indicated that there was an increase in the number of eosinophils migrating through the filter up to $3 \mathrm{~h}$ with no change in the relative effects of PAFacether and $\mathrm{LTB}_{4}$ (Fig. 5).

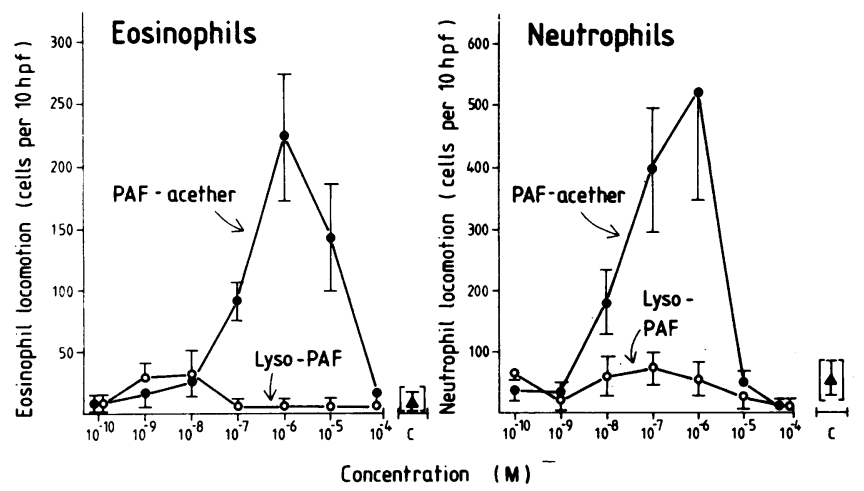

Figure 1. Comparison of the effects of PAF-acether (๑) and lyso-PAF (O) on human eosinophil and neutrophil locomotion. ( $\Delta$ ) Diluent control. $n=4$. Granulocyte locomotion was expressed as the number of cells per $10 \mathrm{hpf}( \pm \mathrm{SEM})$. PAF-acether was significantly more effective than buffer and lyso-PAF $\left(P<0.01,10^{-6} \mathrm{M} ; P<0.05,10^{-7}\right.$ to $\left.10^{-5} \mathrm{M}\right)$. 


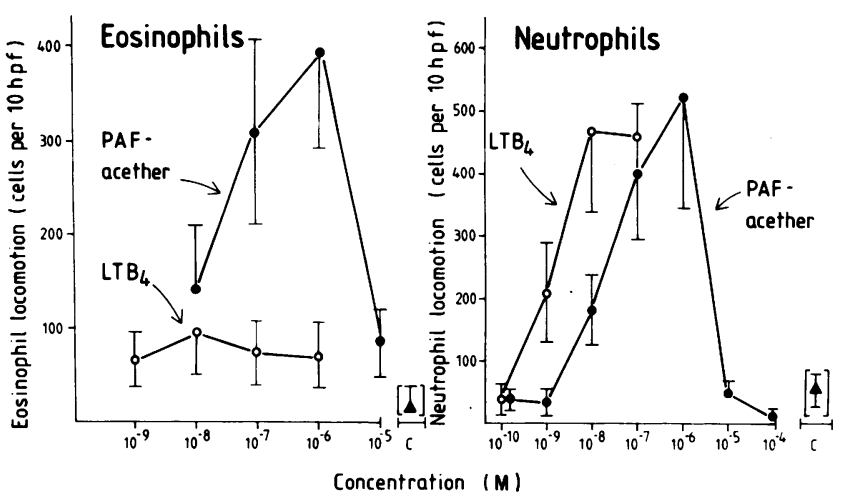

Figure 2. Comparison of the effects of PAF-acether (•) and $\mathrm{LTB}_{4}(0)$ on human eosinophil and neutrophil locomotion. ( $\Delta$ ) Diluent control. $n=5$. Granulocyte locomotion was expressed as the number of cells per $10 \mathrm{hpf}( \pm \mathrm{SEM})$. PAF-acether was significantly more effective than buffer $\left(P<0.01,10^{-6} \mathrm{M} ; P<0.05,10^{-5} / 10^{-7} / 10^{-8} \mathrm{M}\right)$ and $\mathrm{LTB}_{4}(P$ $\left.<0.01,10^{-6} \mathrm{M} ; P<0.05,10^{-7} \mathrm{M}\right)$.

There was no qualitative difference in the response of normal density and light density eosinophils to PAF-acether or the other chemoattractants (Fig. 6). PAF-acether in each case was considerably more potent than the other chemoattractants that demonstrated an inconsistent response, which, in the case of histamine and the two ECF-A tetrapeptides, was no greater than background. There appeared to be a greater locomotory response by light density compared with normal density eosinophils to PAF-acether and $\mathrm{LTB}_{4}$. However, direct comparisons of cell counts between light and normal density eosinophils are not reliable due to the considerable interassay coefficient of variation and because the eosinophils were obtained from different donors. It proved impossible to obtain eosinophils of both types in sufficient numbers from the same donor. Mixing eosinophils with varying numbers of neutrophils demonstrated that reducing the number of eosinophils in the upper chamber was associated with a reduction in the number of eosinophils migrating through the filter under the influence of PAF-acether (Table I). This demonstrates that it is unlikely PAF-acether exerts its effect on eosinophils through stimulation of release of neutrophil-derived mediators.

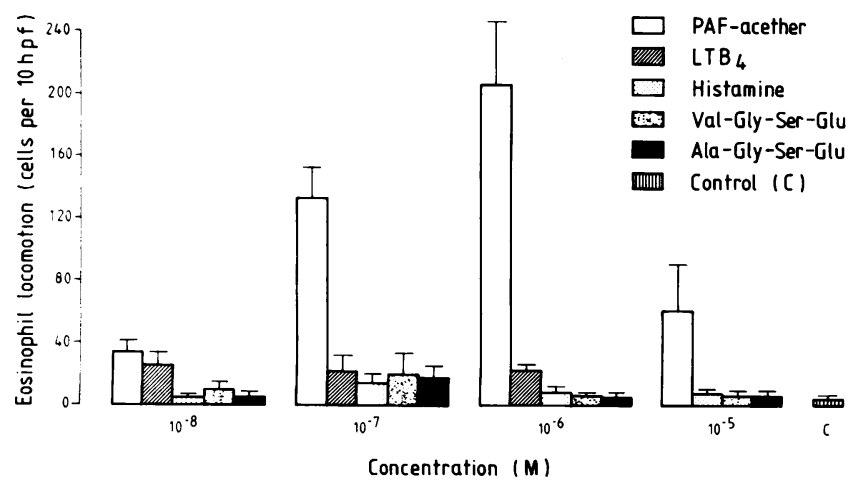

Figure 3. Comparison of the effects of PAF-acether, histamine, valineglycine-serine glutaminic acid, and alanine-glycine-serine-glutaminic acid on human eosinophil locomotion. ( $\triangle$ ) Diluent control. $n=4$. Eosinophil locomotion was expressed as the number of cells per $10 \mathrm{hpf}$ $( \pm$ SEM). PAF-acether was significantly more effective than histamine and the two ECF-A tetrapeptides $\left(P<0.02,10^{-6}\right.$ to $\left.10^{-8} \mathrm{M}\right)$.

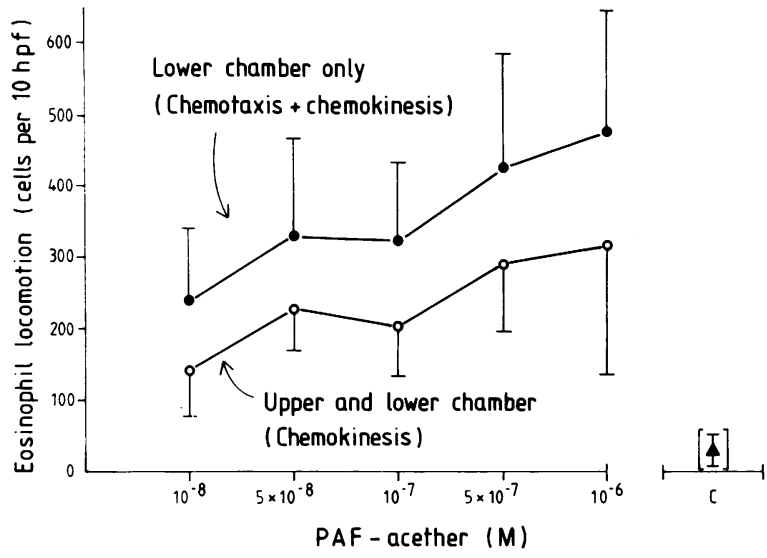

Figure 4. Analysis of the relative contributions of chemokinesis (0) and chemotaxis + chemokinesis (๑) to PAF-acether-induced eosinophil locomotion. ( $\triangle$ ) Diluent control. $n=3$. Eosinophil locomotion was expressed as the number of cells per $10 \mathrm{hpf}( \pm$ SEM). The combination of chemotaxis and chemokinesis was significantly greater than the chemokinetic effect alone $(P<0.01)$.

\section{Discussion}

Eosinophils are thought to play an important part in the pathogenesis of several diseases, particularly those associated with helminthic parasitic infections and allergic inflammation (25). Recent studies have reinforced the view that eosinophils have a potentially damaging role in that they have been shown to be capable of releasing several inflammatory mediators including $\mathrm{LTC}_{4}(26)$ and PAF-acether (6), as well as granule-derived proteins such as major basic protein. Major basic protein, for example, has been shown to damage tracheal epithelium and causes degranulation of mast cells $(27,28)$. In addition, there have been several recent clinical studies which have emphasized the importance of eosinophils in asthma. These have indicated that there is an association among peripheral blood eosinophils, lung

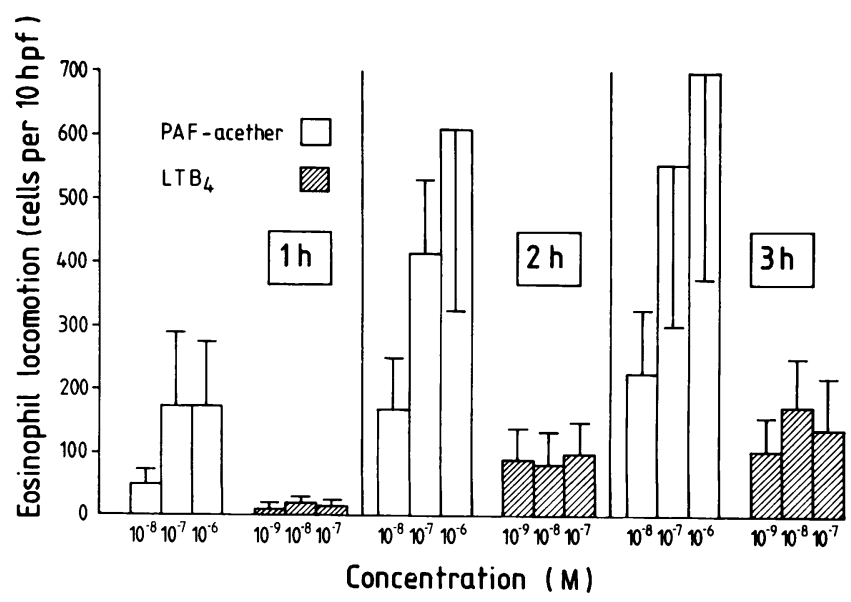

Figure 5. Time course of incubation of eosinophils with either PAFacether ( $\square$ ) or $\mathrm{LTB}_{4}(\mathrm{~g})$ at 1,2 , and $3 \mathrm{~h}$. Three concentrations of each chemoattractant were used at each time point. Values for the diluent control were $5 \pm-2(1 \mathrm{~h}), 42 \pm 29(2 \mathrm{~h})$, and $53 \pm 24(3 \mathrm{~h})$ eosinophils per $10 \mathrm{hpf} . n=3$. Eosinophil locomotion was expressed as the number of cells per $10 \mathrm{hpf}( \pm \mathrm{SEM})$. 


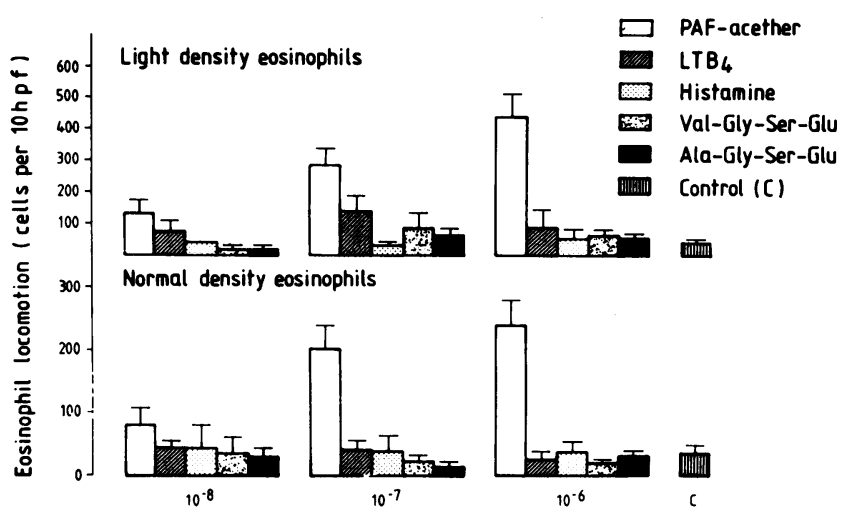

Concentration (M)

Figure 6. Comparison of the effect of PAF-acether, $\mathrm{LTB}_{4}$, histamine, and the two ECF-A tetrapeptides on locomotion by light density ( $n$ $=5$ ) and normal density $(n=4)$ eosinophils. Donors were different for the two cell populations and experiments for the two cell types were performed separately. Eosinophil locomotion was expressed as the number of cells per $10 \mathrm{hpf}( \pm \mathrm{SEM})$

function, and airway hyperreactivity $(29,30)$. Several studies of bronchoalveolar lavage in asthmatics have shown eosinophils and eosinophil granule products to be present in increased numbers when compared with controls (31-33), particularly during a late response to antigen challenge $(34,35)$.

Despite the potential importance of eosinophils in allergic disease, it is still unclear as to which mediators are responsible for attracting eosinophils to the site of inflammation. Since the discovery of an eosinophil chemotactic activity of anaphylaxis (ECF-A) in supernatant from human chopped lung challenged with antigen (36), many eosinophilotactic agents have been described that may be relevant in allergic disease (37). Most of the activity in the challenged lung supernatants resides in the low molecular weight fraction $360-1,000$. Two tetrapeptides, valineglycine-serine-glutaminic acid and alanine-glycine-serine-glutaminic acid, were derived from human lung by extraction with butanol/acetic acid or $1 \mathrm{M} \mathrm{NaCl}$, and these have been considered to comprise part of the activity contained in the challenged lung supernatants (38). However, the activity of these peptides was variable in the dose-response pattern and ineffective with the cells of some donors (39). Other possible contributors to the

Table I. Comparison of the Effect of Eosinophil/Neutrophil Ratios on PAF-Acether-induced $\left(10^{-6} \mathrm{M}\right)$ Eosinophil Locomotion

\begin{tabular}{|c|c|c|c|c|}
\hline \multirow[b]{2}{*}{ Eosinophils } & \multicolumn{3}{|l|}{ Experiment } & \multirow[b]{2}{*}{ Mean \pm SEM } \\
\hline & 1 & 2 & 3 & \\
\hline$\%$ & & & & $\begin{array}{l}\text { Eosinophils/ } \\
10 \text { hpf }\end{array}$ \\
\hline $90-98$ & $300(27)$ & $574(46)$ & $629(195)$ & $501 \pm 101$ \\
\hline 75 & 256 (19) & $604(38)$ & $576(65)$ & $478 \pm 111$ \\
\hline 50 & $128(6)$ & $372(45)$ & $510(147)$ & $337 \pm 112$ \\
\hline 25 & $94(8)$ & $381(9)$ & $352(126)$ & $276 \pm 91$ \\
\hline
\end{tabular}

Eosinophils were of normal density and assays were performed using the microchemotaxis method. Neutrophils were from the same donor and all the cells were granulocytes. Background locomotion to diluent is given in parentheses.
ECF-A activity include histamine, which has been reported as having eosinophilotactic activity (40), and $\mathrm{LTB}_{4}$, which is generally regarded as being the most potent fully characterized mediator of eosinophil locomotion so far described (41).

We have found that $\mathrm{LTB}_{4}$ has an effect on eosinophils similar to that described by Nagy et al. (41), both in terms of absolute counts and the relative effectiveness of $\mathrm{LTB}_{4}$ for neutrophils and eosinophils. $\mathrm{LTB}_{4}$ did not, however, show a clear dose-dependent effect. One explanation for this may be a differential effect on light density and normal density eosinophils inasmuch as a clearer pattern was observed with a homogeneous population of light density eosinophils.

The effect of each of these mediators on eosinophil locomotion was minimal compared with PAF-acether over a dose range of $10^{-8}$ to $10^{-6} \mathrm{M}$. The negligible effect of lyso-PAF is consistent with the effect of PAF-acether and lyso-PAF in other biological systems, such as platelet activation where lyso-PAF is inactive (8). PAF-acether has been shown to be generated by a number of human cell types including neutrophils, eosinophils, platelets, macrophages, and possibly mast cells (2). It is difficult to relate amounts of PAF-acether generated by cells in vitro to the likely concentrations found at inflammatory sites in vivo. In addition, there are few studies which have quantified PAFacether generation in vivo. Nevertheless, neutrophils and normal density eosinophils have been shown to release $1 \mathrm{ng}$ of PAFacether per $10^{6}$ cells after stimulation with the calcium ionophore A23187 (42), and light density eosinophils can release up to 100 $\mathrm{ng} / 10^{6}$ cells (although these findings are in conflict with another study where $<5 \mathrm{pg}$ of PAF-acether were generated by normal density eosinophils [43]). This suggests that activated cells have a considerably enhanced capacity to release PAF-acether, which could result in concentrations in the range $10^{-8}$ to $10^{-6} \mathrm{M}$, which we have found to be chemotactic for eosinophils.

It is well recognized that eosinophils are heterogeneous, consisting of normal density and light density cells that differ in their functional and morphologic properties (21). The light density cells that are found in patients with an eosinophilia are generally regarded as being more activated than normal density cells (44). The eosinophils used in our study are obtained from patients with a considerable eosinophilia and are predominantly of light density. However, comparison of homogeneous cell populations demonstrates that there is no qualitative difference between the two, although there does appear to be greater locomotion to PAF-acether and $\mathrm{LTB}_{4}$ by light density eosinophils.

There are few reports of the in vivo effect of PAF-acether on humans. It had little effect on the vasculature of the nasal mucosa (45), but caused a wheal and flare reaction in the skin with some subjects showing an early and late response (12). Biopsy of the skin reaction revealed a florid infiltration of inflammatory cells but without any predominance of eosinophils. However, there was an increase in eosinophils in bronchoalveolar lavage fluid from baboons $1 \mathrm{~h}$ after challenge with aerosols of PAF-acether (15).

Our experiments involved the use of mixed granulocyte populations, and PAF-acether has been shown to degranulate human neutrophils (13), although cytochalasin B was a necessary requirement in this study. It is possible therefore that the effects of PAF-acether on eosinophils could be mediated in part by neutrophil-derived products. We feel however that this is unlikely, inasmuch as there was a clear association between the percentage of eosinophils and the degree of chemotaxis so that maximal chemotaxis was seen with $>90 \%$ pure eosinophils. In 
addition, neutrophils placed in the lower compartment of the chamber together with PAF-acether did not affect the degree of eosinophil locomotion (data not shown).

In conclusion, our results have shown that PAF-acether is an extremely effective chemotactic factor for human eosinophils. It is generated by several human cell types, and could therefore play a major role in attracting eosinophils to the site of allergic inflammation.

\section{Acknowledgments}

This study was supported by the Wellcome Trust and the Medical Research Council.

\section{References}

1. Hanahan, D. J., C. A. Demopoulos, J. Liehr, and R. N. Pinchard. 1980. Identification of platelet-activating factor isolated from rabbit basophils of acetyl glyceryl ether phosphorylcholine. J. Biol. Chem. 255: 5514-5516.

2. O'Flaherty, J. T., and R. L. Wykle. 1983. Biology and biochemistry of platelet-activating factor. Clin. Rev. Allergy. 1:353-367.

3. Benveniste, J., P. M. Henson, and C. G. Cochrane. 1972. Leucocyte dependent histamine release from rabbit platelets: the role of $\mathrm{IgE}$ basophils and platelet activating factor. J. Exp. Med. 136:1356-1377.

4. Arnoux, B., D. David, and J. Benveniste. 1980. Release of plateletactivating factor (Paf-acether) from alveolar macrophages by the calcium ionophore A23187 and phagocytosis. Eur. J. Clin. Invest. 10:437-441.

5. Sanchez-Crespo, M., F. Alonso, and J. Figaro. 1980. Platelet activating factor in anaphylaxis and phagocytosis. I. Release from human peripheral polymorphonuclear and monocytes during the stimulation by ionophore A23187 and phagocytosis but not from degranulating basophils. Immunology. 40:645-655.

6. Jouvin-Marche, E., J. M. Grzych, C. Boullet, M. Capron, and J. Benveniste. 1984. Formation of Paf-acether by human eosinophils. Fed. Proc. 43:1924. (Abstr.)

7. Camussi, G., M. Aglietta, F. Malavasi, C. Tetta, W. Piacibello, F. Sanavio, and F. Bussolino. 1983. The release of platelet-activating factor from human endothelial cells in culture. J. Immunol. 131:2397-2403.

8. McManus, L. M., D. J. Hanahan, and R. N. Pinckard. 1981. Human platelet stimulation by acetyl glyceryl ether phosphorylcholine. J. Clin. Invest. 67:903-906.

9. Gateau, B., B. Arnoux, H. Deriaz, P. Viars, and J. Benveniste. 1984. Acute effects of intratracheal administration of Paf-acether (platelet activating factor) in humans. Am. Rev. Respir. Dis. 129:A3. (Abstr.)

10. Czarnetzki, B. 1983. Increased monocyte chemotaxis towards leukotriene $\mathrm{B}_{4}$ and platelet activating factor in patients with inflammatory dermatoses. Clin. Exp. Immunol. 54:486-492.

11. Archer, C. B., C. P. Page, J. Morley, and D. M. MacDonald. 1985. Accumulation of inflammatory cells in response to intracutaneous platelet activating factor (Paf-acether) in man. Br. J. Dermatol. 112:285290.

12. O'Flaherty, J. T., R. L. Wykle, C. H. Miller, J. C. Lewis, M. Waite, A. Bass, C. E. McCall, and L. R. De Chatelet. 1981. 1-O-Alkyl$s n$-glyceryl-3-phosphorylcholines: a novel class of neutrophil stimulation. Am. J. Pathol. 103:70-79.

13. Shaw, J. O., R. N. Pinckard, K. S. Ferrigni, L. M. McManus, and D. J. Hanahan. 1981. Activation of human neutrophils with 1-OHexadecyl/octadecyl-2-acetyl-sn-glyceryl-3-phosphorylcholine (platelet activation factor). J. Immunol. 127:1250-1255.

14. Bruynzeel, P. L. B., P. T. M. Kok, M. L. Hamelink, A. M. Kijne, and J. Verhagen. 1985. Exclusive leukotriene $C_{4}$ synthesis by purified human eosinophils induced by opsonized zymosan. FEBS (Fed. Eur. Biochem. Soc.) Lett. 189:350-354.

15. Denjean, A., B. Arnoux, A. Lockhart, R. Masse, and J. Benveniste.
1984. Modification of alveolar cell population after Paf-acether induced bronchoconstriction in baboons. Am. Rev. Respir. Dis. 129:A3. (Abstr.)

16. Czarnetzki, B. M., and J. Grabbe. 1983. Biological and chemical characterisation of eosinophil chemotactic factors from human leucocytes. In Leukocyte Locomotion and Chemotaxis. H. Keller, G. O. Till, and A. Arbor, editors. Birkhäuser Verlag, Basel. 204-215.

17. Jackson, E. M., G. E. Mott, C. Hoppens, and L. M. McManus. 1984. High performance liquid chromatography of platelet-activating factors. J. Lipid Res. 125:753-757.

18. Cromwell, O., R. J. Shaw, G. M. Walsh, A. I. Mallet, and A. B. Kay. 1985. Inhibition of leukotriene $C_{4}$ and $B_{4}$ generation by human eosinophils and neutrophils with the lipoxygenase pathway inhibitors U-60,257 and BW755C. Int. J. Immunopharmacol. 7:775-781.

19. Kimura, I., Y. Moritani, and Y. Tanizaki. 1973. Basophils in bronchial asthma with reference to reagin-type allergy. Clin. Allergy. 3: 195-202.

20. Kay, A. B. 1970. Studies on eosinophil leucocyte migration. II. Factors specifically chemotactic for eosinophils and neutrophils generated from guinea-pig serum by antigen-coated complexes. Clin. Exp. Immunol. 7:723-727.

21. Prin, L., M. Capron, A. B. Tonnel, O. Bletry, and A. Capron. 1983. Heterogeneity of human peripheral blood eosinophils: variability in cell density and cytotoxic ability in relation to the level and the origin of hypereosinophilia. Int. Arch. Allergy Appl. Immunol. 72:336-346.

22. Vadas, M. A., J. R. David, A. Butterworth, N. T. Pisani, and T. A. Siongok. 1979. A new method for the purification of human eosinophils and neutrophils, and a comparison of the ability of these cells to damage schistosomula of Schistosoma mansoni. J. Immunol. 122: 1228-1238.

23. Falk, W., R. H. Goodwin, Jr., and E. J. Leonard. 1980. A 48well micro chemotaxis assembly for rapid and accurate measurement of leukocyte migration. J. Immunol. Methods. 33:239-247.

24. Zigmond, S. H., and J. G. Hirsch. 1973. Leukocyte locomotion and chemotaxis. New Methods for evaluation, and demonstration of a cell-derived chemotactic factor. J. Exp. Med. 137:387-410.

25. Weller, P. F. 1984. Eosinophilia. J. Allergy Clin. Immunol. 73: $1-9$.

26. Shaw, R. J., G. M. Walsh, O. Cromwell, R. Moqbel, C. J. F. Spry, and A. B. Kay. 1985. Activated human eosinophils generate SRS-A leukotrienes following IgG-dependent stimulation. Nature (Lond.). 316:150-152.

27. Gleich, G. J., E. Frigas, D. A. Loegering, D. L. Wassom, and D. Steinmuller. 1979. Communication. Cytotoxic properties of the eosinophil major basic protein. J. Immunol. 123:2925-2927.

28. O'Donnell, M. C., S. J. Ackerman, G. J. Gleich, and L. L. Thomas. 1983. Activation of basophil and mast cell histamine release by eosinophil granule major basic protein. J. Exp. Med. 157:1981-1991.

29. Horn, B. R., E. D. Robin, J. Theodore, and A. Van Kessel. 1975. Total eosinophil counts in the management of bronchial asthma. $N$. Engl. J. Med. 292:1152-1155.

30. Durham, S. R., and A. B. Kay. 1985. Eosinophils, bronchial hyperreactivity and late-phase asthmatic reactions. Clin. Allergy. 15:411418.

31. Diaz, P., F. R. Galleguillos, M. C. Gonzalez, C. F. A. Pantin, and A. B. Kay. 1984. Bronchoalveolar lavage in asthma: the effect of disodium cromoglycate (cromolyn) on leukocyte counts, immunoglobulins, and complement. J. Allergy Clin. Immunol. 74:41-48.

32. Godard, P., J. Chaintreuil, M. Damon, M. Coupe, O. Flandre, A. Crastes de Paulet, and F. B. Michel. 1982. Functional assessment of alveolar macrophages: comparison of cells from asthmatics and normal subjects. J. Allergy Clin. Immunol. 70:88-93.

33. Kay, A. B., A. J. Wardlaw, J. V. Collins, S. Dunnette, and G. J. Gleich. 1986. Eosinophil and major basic protein in bronchoalveolar lavage in asthma: relationship to nonspecific hyperreactivity. J. Allergy Clin. Immunol. 77:236. (Abstr.)

34. De Monchy, J. G. R., H. F. Kauffman, P. Venge, G. H. Koëter, H. M. Jansen, H. J. Sluiter, and K. De Vries. 1985. Bronchoalveolar 
eosinophilia during allergen-induced late asthmatic reactions. Am. Rev. Respir. Dis. 131:373-376.

35. Metzger, W. J., G. W. Hunninghake, and H. B. Richerson. 1985. Late asthmatic responses: inquiry into mechanisms and significance. Clin. Rev. Allergy. 3:145-165.

36. Kay, A. B., and K. F. Austen. 1971. The IgE-mediated release of an eosinophil leukocyte chemotactic factor from human lung. J. Immunol. 107:899-902.

37. Kay, A. B. 1985. Review. Eosinophils as effector cells in immunity and hypersensitivity disorders. Clin. Exp. Immunol. 62:1-12.

38. Goetzl, E. J., and K. F. Austen. 1975. Purification and synthesis of eosinophilotactic tetrapeptides of human lung tissue. Identification as eosinophil chemotactic factor of anaphylaxis. Proc. Natl. Acad. Sci. USA 72:4123-4127.

39. Goetzl, E. J., and K. F. Austen. 1980. Natural eosinophilotactic peptides: evidence of heterogeneity and studies of structure and function. In The Eosinophil in Health and Disease. A. A. F. Mahmoud, and K. F. Austen, editors. Grune \& Stratton, New York. 149-165.
40. Clark, R. A. F., J. I. Gallin, and A. P. Kaplan. 1975. The selective eosinophil chemotactic activity of histamine. J. Exp. Med. 142:14621470.

41. Nagy, L., T. H. Lee, E. J. Goetzl, W. C. Pickett, and A. B. Kay. 1982. Complement receptor enhancement and chemotaxis of human neutrophils and eosinophils by leukotrienes and other lipoxygenase products. Clin. Exp. Immunol. 47:541-547.

42. Makoto, O., S. Kiyoshi, K. Yascunoja, and K. Sacho. 1985. Molecular species of platelet-activating factor generated by human neutrophils challenged with ionophore A23187. J. Immunol. 134:1090-1093.

43. Lee, T. C., D. J. Lenihan, B. Malone, L. L. Ruddy, and S. I. Wasserman. 1984. Increased biosynthesis of platelet-activating factor in activated human eosinophils. J. Biol. Chem. 259:5526-5530.

44. Spry, C. J. F. 1985. Synthesis and secretion of eosinophil granule substances. Immunol. Today. 6:332-335.

45. Pipkorn, U., G. Karlsson, and B. Bake. 1984. Effect of platelet activating factor on the human nasal mucosa. Allergy. 39:141-145. 